Vol. 1, No. 2, Juni 2021

\title{
PENINGKATAN KEPATUHAN WAJIB PAJAK USAHA KECIL MENENGAH MELALUI PELATIHAN PEMANFAATAN SISTEM INFORMASI PERPAJAKAN
}

\author{
Bq. Anggun Hilendri Lestari \\ Fakultas Ekonomi Dan Bisnis Universitas Mataram \\ hilendria@unram.ac.id \\ L. Takdir Jumaidy \\ Fakultas Ekonomi Dan Bisnis Universitas Mataram \\ takdirjumaidy@yahoo.com \\ D. Tiallurra Della Nabila \\ Fakultas Ekonomi Dan Bisnis Universitas Mataram \\ tialurradellanabila@unram.ac.id
}

\section{Article History: \\ Received: 23 April 2021 \\ Revised: - \\ Accepted: 6 Juni 2021 \\ DOI: \\ 10.29303/abdimassangkabi ra.v1i2.32}

\begin{abstract}
This community service activity aims to train small and medium business owners in using the tax information system. The method used in carrying out this activity is training on the use of tax information systems accompanied by continuous assistance in the form of consultations if there is a problem in using the application in the system. Based on the results of community service, it can be concluded that community service partners have complied with their tax obligations by utilizing $e$ filling, which is one of the tax systems designed by the Directorate General of Taxes to make it easier for taxpayers to pay their taxes. In addition, the Directorate General of Taxes has upgraded its tax system and service partners have difficulty using it.
\end{abstract}

Keywords: tax information systems, small and medium business

\section{Pendahuluan}

Pajak memiliki peranan yang penting dalam menyumbangkan penerimaaan negara. Sebagai sumber pembiayaan negara dan pembangunan nasional, pajak menyumbang hampir $80 \%$ dari total penerimaan Indonesia. Pajak dalam pemungutannya selain membutuhkan partisipasi aktif para pegawai pajak, yang paling dibutuhkan juga adalah kesadaran dari wajib pajak untuk membayar pajak. Penerimaan negara melalui pajak di Indonesia dihimpun oleh Direktorat Jenderal Pajak (Novitasari, 2021).

Direktorat Jenderal Pajak terus melakukan transformasi digital guna meningkatkan kualitas layanan dan meningkatkan efektivitas pengawasan terhadap kepatuhan wajib pajak untuk menyesuaikan diri 
dengan perkembangan zaman. Bentuk reformasi perpajakan tersebut berupa modernisasi teknologi informasi perpajakan. Salah satu pembaruan yang dilakukan adalah menerapkan teknologi informasi terbaru dalam pelayananan pajak. Direktorat Jenderal Pajak mengeluarkan sistem administrasi perpajakan yang memanfaatkan teknologi yaitu $e$ System atau Electronic System. Sistem elektronik untuk administrasi pajak tersebut diantaranya adala $h$ e-Registration, e-Filling, e-SPT, dan e-Billing pada awal tahun 2005. Modernisasi teknologi ini diyakini akan menjadi salah satu pilar penting dari reformasi perpajakan karena akan sangat bermanfaat sebagai upaya peningkatan tax ratio, penghindaran dan penggelapan pajak, serta mendorong kepatuhan wajib pajak (Novitasari, 2021).

Adanya sistem yang disediakan oleh Direktorat Jendral Pajak ini, Wajib Pajak diharapkan meningkatkan kepatuhan dan lebih mudah untuk melaksanakan kewajiban perpajakan terutama dalam melaporkan SPT tanpa harus mengantri di Kantor Pelayanan Pajak sehingga efektif dan efisien. Selain itu, pengiriman data Surat Pemberitahuan (SPT) dapat dilakukan dimana saja dan kapan saja, dimana data akan dikirim langsung ke database Direktorat Jendral Pajak dengan fasilitas internet yang disalurkan melalui website Direktorat Jendral Pajak (DJP). Tak terkecuali Usaha Kecil Menengah (UKM) yang merupakan wajib pajak potensial bagi negara.

Usaha Kecil dan Menengah (UKM) adalah bagian penting dari perekonomian suatu negara maupun daerah, Ketahanan perekonomian suatu Negara sangat ditentukan oleh kuatnya UKM. Pengusaha UKM umumnya kuat atas gejolak yang terjadi pada perekonomian dunia (Siambaton, 2015). Permasalahannya apakah para pemilik UKM memanfaatkan sistem informasi perpajakan tersebut? Kegiatan ini bermaksud melatih para pemilik UKM dalam menggunakan sistem informasi perpajakan tersebut.

\section{Metode}

Metode yang digunakan dalam melaksanakan kegiatan ini adalah pelatihan pemanfaatan sistem informasi perpajakan disertai pendampingan berkelanjutan berupa konsultasi jika terjadi masalah dalam penggunaan aplikasi dalam sistem tersebut.

a. Tahap 1 (Jangka Waktu 2 bulan)

1. Observasi dan Persiapan (2 minggu)

Observasi dan persiapan dilakukan dalam rangka mempersiapkan segala sesuatunya yang terkait dengan kegiatan pelatihan yang akan dilakukan, seperti pembuatan modul yang nantinya akan dijadikan panduan oleh pemilik UKM

2. Pelatihan (2 minggu) 


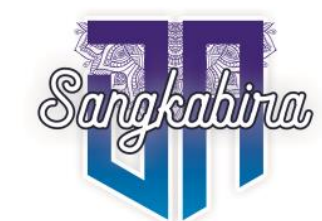

Vol. 1, No. 2, Juni 2021

Pelatihan manfaatan system informasi perpajakan akan difasilitasi oleh tim pengabdian pada masyarakat dengan fokus pelatihan pada pemenuhan kewajiban perpajakan UKM.

3. Pendampingan ( 2 bulan)

Setelah pelatihan, selanjutnya tim pengabdian pada masyarakat melakukan pendampingan. Pendampingan ini perlu dilakukan untuk memastikan para pemilik UKM memenuhi kewajiban perpajakannya tepat waktu tanpa mengalami kesulitan.

b. Tahap 2 (Jangka Waktu 1bulan)

Pada tahap kedua ini, dilakukan evaluasi atas kegiatan yang telah dilakukan selama 3 bulan sebelumnya dan pembuatan laporan akhir.

\section{Hasil}

Kegiatan pengabdian kepada masyarakat dilakukan di "CV. RIEN'S CREATIVE MULTIMEDIA" dengan alamat Jl. Raya Tanjung Bayan Dusun Sembaro RT 006 Genggelang, Gangga Kabupaten Lombok Utara Nusa Tenggara Barat, NPWP: 80.593.580.6-914.000. Kegiatan usaha pokok adalah Jasa Fotografi dan videografi multimedia. Berdasarkan hasil pengabdian tim Fakultas Ekonomi dan Bisnis Universitas Mataram dapat dijelaskan bahwa pihak "CV. RIEN'S CREATIVE MULTIMEDIA" telah memenuhi kewajiban perpajakannya yakni patuh atau taat dalam membayar pajak tepat pada waktunya. "CV. RIEN'S CREATIVE MULTIMEDIA" juga memanfaatan sistem informasi perpajakan e-filling, karena menurut pemiliknya dengan e-filling lebih memudahkan proses pemenuhan kewajiban perpajakan mereka. Hanya saja, satu bulan terakhir ini mereka agak kesulitan menggunakan sistem perpajakan yang baru dari Direktorat Jendral Pajak (DJP). Sistem yang lama ada penyesuaian oleh DJP sehingga mereka agak kesulitan menggunakannya, sehingga menurut mereka perlu adanya sosialisasi terkait sistem tersebut.

\section{Diskusi}

Kegiatan pengabdian kepada masyarakat yakni melatih mitra dalam memanfaatkan sistem informasi perpajakan seperti e-filling memberikan hasil bahwa pada dasarnya UKM tidak ketinggalan jauh dengan perkembangan informasi terkait administrasi perpajakan. UKM tetap melakukan up date informasi dikarenakan kebutuhan mereka juga dalam menyelesaikan kewajiban perpajakan mereka. Hanya saja, menurut mereka perlu adanya sosialisasi terlebih dahulu oleh DJP jika mengadakan pembaharuan sistem administrasi perpajakan, agar mereka tidak kebingungan untuk menggunakan sistem yang baru. Oleh karena itu, melalui kegiatan pengabdian kepada masyarakat ini diharapkan adanya masukan kepada pihak DJP oleh tim pengabdian. 


\section{Kesimpulan}

Berdasarkan hasil pengabdian kepada masyarakat dapat disimpulkan bahwa "CV. RIEN'S CREATIVE MULTIMEDIA" telah patuh dalam melaksanakan kewajiban perpajakannya dengan memanfaatkan $e$ filling yang merupakan salah satu sistem perpajakan yang dirancang oleh Direktorat Jendral Pajak untuk memudahkan para wajib pajak membayar pajaknya. Selain itu, Direktorat Jendral Pajak telah mengup-grade sistem perpajakannya dan "CV. RIEN'S CREATIVE MULTIMEDIA" kesulitan untuk menggunakannya.

\section{Pengakuan}

Terima kasih kami sampaikan kepada pihak-pihak yang turut terlibat langsung dalam mesukseskan kegiatan pengabdian kepada masyarakat ini yakni: Bapak Ahmad Sianturi selaku pemilik "CV. RIEN'S CREATIVE MULTIMEDIA" dan tim pengabdian kepada masyarakat Ibu Bq. Anggun Hilendri Lestari selaku Ketua tim, Bapak L. Takdir Jumaidy, dan Ibu D.Tialurra Della Nabila.

\section{Daftar Pustaka}

Novitasari, L. (2021). Modernisasi Teknologi Informasi Perpajakan di Era Ekonomi Digital. DJP. https://www.pajak.go.id/id/artikel/modernisasiteknologi-informasi-perpajakan-di-era-ekonomi-digital

Siambaton, E. (2015). Survey Kepatuhan Wajib Pajak Pengusaha Ukm Di Kotamadya Depok. 14(1), 1-6. 